\title{
Hepatic pseudoaneurysm secondary to blunt trauma successfully treated with percutaneous transhepatic intervention
}

\author{
Orhan Ozbek, ${ }^{1}$ Yalcin Solak, ${ }^{2}$ Abdussamed Batur, ${ }^{1}$ Abduzhappar Gaipov ${ }^{2}$ \\ ${ }^{1}$ Department of Radiology, Meram School of Medicine, Konya University, Meram, Konya, Turkey \\ ${ }^{2}$ Division of Nephrology, Department of Internal Medicine, Meram School of Medicine, Konya University, Meram, Konya, Turkey \\ Correspondence to Dr Abduzhappar Gaipov, abduzhappar@gmail.com
}

\section{DESCRIPTION}

A 25-year-old man presented to the emergency department with haematemesis, which was occasionally repeated during the last 3 months. The patient had been severely beaten 3 months ago. Gastroscopy was performed to identify the reason of haematemesis, but we did not find any pathological condition in the upper gastrointestinal tract. Abdominal ultrasonography revealed a lesion, which seemed to be a haematoma, in the right liver lobe adjacent to the gall bladder. Abdominal CT showed a haematoma in the right anterior lobe of the liver measuring $89 \times 78 \mathrm{~mm}$. There was a pseudoaneurysm in the haematoma area next to the right hepatic artery with a diameter of $19 \times 11 \mathrm{~mm}$ (figure 1 ).

Digital subtraction angiography revealed that the pseudoaneurysm originated from the right hepatic artery with a narrow neck (figure 1A). We could not reach the lumen of the pseudoaneurysm using a microcatheter because of the narrow neck. Digital subtraction angiography confirmed a pseudoaneurysm of the right hepatic artery origin (figure 1B). We thought that the pseudoaneurysm was opened to the biliary tract and caused haemobilia.

The pseudoaneurysm was reached through a percutaneous transhepatic route with a $20 \mathrm{G}$ Chiba needle and was coagulated with thrombin injection (figure 1C). The pseudoaneurysm is embolised completely after $24 \mathrm{~h}$ of thrombin injection. Control CT images showed complete thrombosis of the pseudoaneurysm (figure 1D). After coagulation of the pseudoaneurysm, bleeding has not recurred for approximately 6 months.

Hepatic artery pseudoaneurysms are late complications of iatrogenic interventions to the liver or blunt abdominal trauma. These pseudoaneurysms frequently rupture into the biliary tract ${ }^{1}$ or the peritoneum ${ }^{2}$ and have a high death rate.

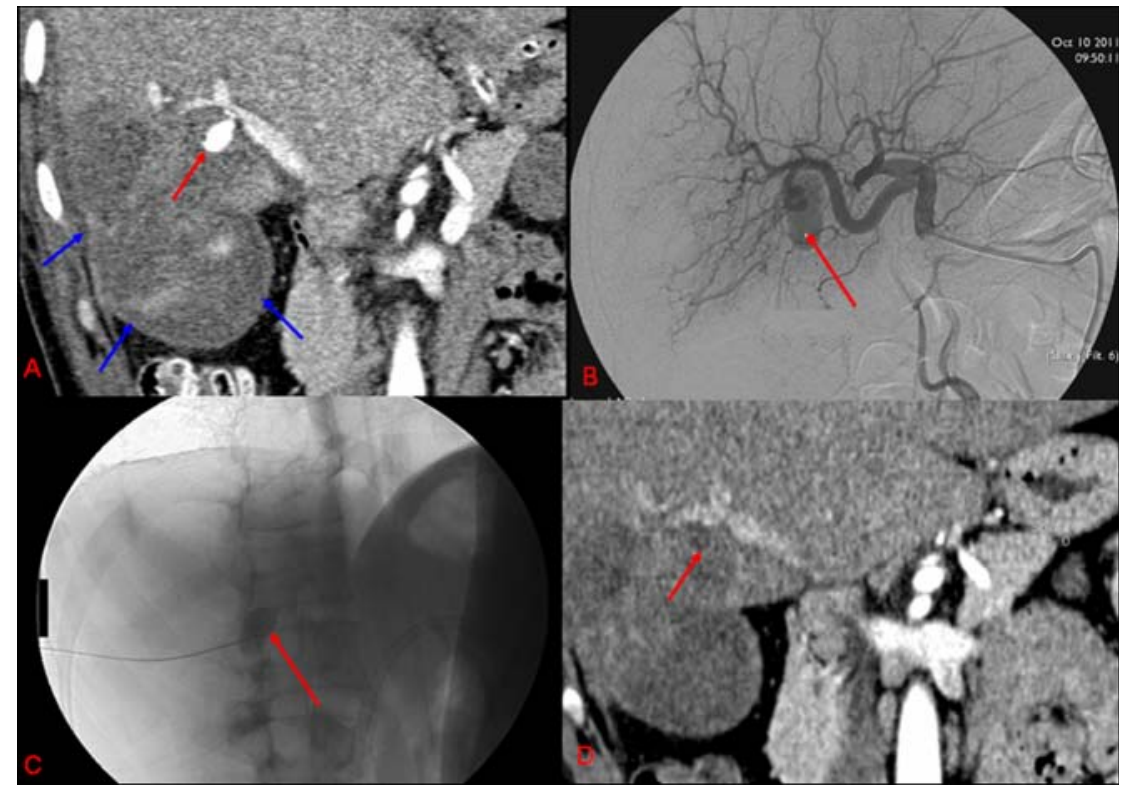

Figure 1 (A) Coronal reformatted CT imaging: a pseudoaneurysm originating from the right hepatic artery. (B) Digital subtraction angiography confirms a pseudoaneurysm originating from the right hepatic artery. (C) Thrombin administration into a pseudoaneurysm through an ultrasound-guided percutaneous transhepatic route. (D) Coronal reformatted control CT imaging: note that the pseudoaneurysm is embolised completely after $24 \mathrm{~h}$ of thrombin injection. 


\section{BMJ Case Reports}

Competing interests None.

Patient consent Obtained.

\section{REFERENCES}

1. Wagner WH, Allins $A D$, Treiman RL, et al. Ruptured visceral artery aneurysms. Ann Vasc Surg 1997;11:342-7.

2. Abbas MA, Fowl RJ, Stone WM, et al. Hepatic artery aneurysm: factors that predict complications. J Vasc Surg 2003;38:41-5.

This pdf has been created automatically from the final edited text and images.

Copyright 2012 BMJ Publishing Group. All rights reserved. For permission to reuse any of this content visit http://group.bmj.com/group/rights-licensing/permissions.

BMJ Case Report Fellows may re-use this article for personal use and teaching without any further permission.

Please cite this article as follows (you will need to access the article online to obtain the date of publication).

Ozbek O, Solak Y, Batur A, Gaipov A. Hepatic pseudoaneurysm secondary to blunt trauma successfully treated with percutaneous transhepatic intervention. BMJ Case Reports 2012;10.1136/bcr-2012-006239, Published XXX

Become a Fellow of BMJ Case Reports today and you can:

- Submit as many cases as you like

- Enjoy fast sympathetic peer review and rapid publication of accepted articles

- Access all the published articles

- Re-use any of the published material for personal use and teaching without further permission

For information on Institutional Fellowships contact consortiasales@bmjgroup.com

Visit casereports.bmj.com for more articles like this and to become a Fellow 